\title{
IRON METABOLISM AND THE LIVER WITH PARTICULAR REFERENCE TO THE PATHOGENESIS OF HAEMOCHROMATOSIS
}

\author{
Roger WilliaMs, M.D.(LoND.), M.R.C.P. \\ Lecturer in Medicine \\ C. S. Pitcher, D.M., D.PATH. \\ Senior Lesturer in Hamatology
}

From the Departments of Medicine and Pathology, Royal Free Hospital, London, W.C.I

THE iron storage diseases have always aroused a great deal of interest and this is particularly true at present. One group of workers question Sheldon's (1935) concept of an inborn error of metabolism in idiopathic hæmochromatosis and stress the role of environmental factors such as alcoholism and malnutrition. Other investigators describe early cases of the disease in the younger relatives of these patients and recommend that they should be treated by multiple venesections. The reported development of hæmochromatosis in chronic refractory hypochromic anæmia raises further problems with regard to the toxicity and route of entry of excess iron. The frequency of siderosis in the Bantu with its apparent progression to hæmochromatosis in a definite proportion of cases is of particular interest in relation to the mucosal-block theory of intestinal iron absorption.

Understanding of these diseases can only follow more exact knowledge of the fundamental factors regulating iron absorption. In this paper, therefore, before discussing the pathogenesis of the various types of hæmochromatosis, we shall first consider the factors normally maintaining iron balance.

\section{NORMAL IRON BALANCE}

The total body iron is approximately $4.5 \mathrm{~g}$. of which the majority (2.5 g.) is present in circulating hæmoglobin. A further $600 \mathrm{mg}$. is present in the labile pool and marrow erythrons (Pollycove and Mortimer, 196I). Muscle myoglobin contains $140 \mathrm{mg}$. Very much smaller amounts are present in the plasma iron pool and in the various iron containing enzymes. The remainder, amounting to between I and I.5 g., is stored in the tissues in the form of ferritin or hæmosiderin. The major site of storage is the liver. Loss of iron from the body under normal conditions is extremely small and has been estimated to lie between 0.5 and $1.5 \mathrm{mg}$. per day. Since the normal subject is in a state of iron balance this figure represents the iron requirements of the adult male. It does not take into account the additional requirements for growth in children nor for the menstrual loss in women. A growing child accumulates some $200 \mathrm{mg}$. of iron per year or a little over $0.5 \mathrm{mg}$. per day while the normal menstrual loss averages 0.5 to $1.0 \mathrm{mg}$. per day.

\section{r. Iron Absorption}

The normal daily diet of the European contains between 10 and $15 \mathrm{mg}$. of iron and the percentage absorption in males would therefore be expected to lie between 5 and $10 \%$, children and menstruating women absorbing a higher percentage. The actual measurement of iron absorption has, however, proved extremely difficult, and many workers have reported percentage absorptions in normal subjects which, if applied to the dietary iron intake, would lead to a positive iron balance and rapid accumulation of iron in the body.

The older chemical balance studies have been replaced by methods using radioactive isotopes of iron. The simplest way is to give an oral dose of ${ }^{59} \mathrm{Fe}$ and to collect the stools for a period of 5 to 7 days, the percentage absorption being derived indirectly from the amount recovered. The principal drawback is the difficulty of ensuring complete collection of the fæces and the consequent danger of over-estimation of the amount absorbed. A similar method in which the percentage of the isotope appearing in the peripheral red cells is measured has been used by some workers. While in iron-deficient subjects with rapid and complete utilization of the absorbed radioiron for hæmoglobin synthesis, this may give a good indication of the amount absorbed, in pathological states and even in normal subjects there may be wide variations in percentage of the absorbed iron appearing in the red cells. Dubach, Callender and Moore (1948) combined the two methods but found that a variable and highly significant percentage of the administered radioiron could not be accounted for in either the blood or the fæces.

In an attempt to overcome these difficulties, Bothwell, Pirzio-Biroli and Finch (1958) have used two isotopes of iron. ${ }^{59} \mathrm{Fe}$ is injected intravenously and at the same time ${ }^{55} \mathrm{Fe}$ is given by mouth. The relative amounts of the two isotopes appearing 
in the peripheral red cells at ro days is then determined. The ${ }^{59} \mathrm{Fe}$ is used to indicate the percentage of iron entering the body that is used for hæmoglobin synthesis and it is assumed that the percentage utilization of the absorbed ${ }^{55} \mathrm{Fe}$ will be the same. Thus if $50 \%$ of the ${ }^{59} \mathrm{Fe}$ appears in the red cells, then the amount of ${ }^{55} \mathrm{Fe}$ reaching the red cells represents $50 \%$ of that actually absorbed. Unfortunately the method is technically complex.

More recently, whole-body counting techniques have been applied to the measurement of iron absorption (Van Hoek and Conrad, r 96I ; Price, Cohn, Wasserman, Reizenstein and Cronkite, 1962). A small dose of ${ }^{59} \mathrm{Fe}$ is given orally and 14 days later, after all unabsorbed isotope has left the body, the percentage absorbed is determined. This method has considerable advantages but the counting apparatus is extremely expensive.

Among the various factors that have been found to affect the results of iron absorption tests are the total amount of iron administered, the valency and nature of the salt used and the presence of reducing agents such as ascorbic acid. Much lower figures are obtained if absorption from labelled food rather than an inorganic iron salt is measured, while the size and iron content of any meal given both affect the results of the tests. In the investigation of disorders of iron metabolism it appears particularly important that the methods used should be as nearly physiological as possible. Such unphysiological procedures as the administration of relatively large doses of an inorganic iron salt to a fasting patient are likely to give misleading results.

The normal range. The published results of studies using a dose of ferrous sulphate labelled with ${ }^{59} \mathrm{Fe}$ show a wide normal range. Callender (1962), for instance, found a mean of $27 \%$ with a range of 10 to $70 \%$. A further difficulty is the apparent disagreement between results obtained by whole-body counting techniques and those using stool radioactivity measurements. Van Hœk and Conrad (196r), measuring the absorption of a I mg. dose of ferrous sulphate in 25 normal subjects by whole-body counting found a range of 0.2 to $10 \%$, while Price and others (1962), also using a ferrous salt, found a mean of $15.9 \%$ but no subject absorbed more than $25 \%$ of the dose. While the variations found may represent differences in the iron reserves of the populations studied, they are still very large and it seems doubtful whether any useful information can be obtained by measuring the absorption of inorganic salts of ferrous iron in fasting subjects.

The absorption of inorganic salts of ferric iron has not been frequently measured in man but the figures obtained are considerably lower than for ferrous salts (Moore, Dubach, Minnich an Roberts, 1944).

The absorption of food iron has been measure both by the use of foods labelled in vivo witl ${ }^{59} \mathrm{Fe}$ and by the addition of tracer amounts of radioactive iron salts to foodstuffs. Using th $\overrightarrow{\vec{E}}$ first method, Moore (1955) found that the irof absorption of normal subjects was usually betweef I and $10 \%$ of the dose though occasionall greater. Chodos, Ross, Apt, Pollycove an Halkett (1957) added ferrous iron to various foodstuffs and found that the absorption in norma subjects ranged from 0.5 to $35 \%$. The absorption of the ferrous salt alone, without food, was as high as $75 \%$ in some cases. Pirzio-Biroli, Bothwefy and Finch (1958) using the double isotope technique with a ferric salt found an average absorption in normal subjects of $5.3 \%$ with range of $0.5 \%$ to $17 \%$

Factors affecting the rate of iron absorption. The् amount of iron present in the diet or in the radioactive dose adminstered is of criticad importance. Smith and Pannaciulli (1958\% showed that, as the dose of iron was raised, the total amount absorbed increased steadily althougl the percentage absorption fell. When doses oE. over $100 \mathrm{mg}$. of iron were given, no further increase in the amount absorbed occurred. ON number of other dietary factors may affect the rate of iron absorption. The presence of phse phates and phytates which form insoluble iror salts tends to depress absorption while the additior of ascorbic acid increases the absorption of fooc iron as well as that of inorganic iron salts (Moore을 1955). Some $10 \%$ of hæmoglobin iron is absorbe by normal subjects, but the mechanism of the absorption appears to be different in that the absorption is unaffected by the presence of phytate, ascorbic acid or inorganic iron salts (Turnbull, Cleton, and Finch, 1962).

Iron is believed to be absorbed mainly in the stomach and duodenum but the evidence for this is derived largely from animal experiments 응 Patients who have had a partial gastrectomy with by-pass of the duodenum can absorb inorganic iron salts but show defective absorption of foots iron (Chodos, Ross, Apt, Pollycove and Halkett? 1957). The role of gastric $\mathrm{HCl}$ was investigated by Moore (1955) who found that it did not increase absorption of food iron in subjects with achlorhydria. Biggs, Bannerman and Callende (I962) found the same to be true of normak gastric juice when tested with iron in the form of labelled hæmoglobin.

The exact part played by the intestinal mucosa! cells is imperfectly understood. The concep5 of a 'mucosal block' mechanism was largely based on the observation that the feeding of iron $I$ to $\mathbb{C}_{\mathrm{D}}$ 
hours before a dose of labelled iron reduced the rate of absorption. Granick (1946) found that iron feeding led to increased synthesis in the mucosal cells of a protein, apoferritin, which was capable of combining with ferric iron to form ferritin. He proposed that the accumulation of ferritin in the cell inhibited further absorption of iron until removal of iron into the plasma lowered the ferritin concentration. More recent work, however, throws considerable doubt on the existence of this mechanism. Iron absorption continues in patients whose iron stores are increased and Wöhler, Heilmeyer, Emrich and Kang (1957) have shown that the presence of large amounts of ferritin in the mucosal cells does not inhibit iron absorption in animals.

Iron deficient subjects absorb considerably increased amounts of iron. A single phlebotomy of $500 \mathrm{ml}$. of blood produces an increase in iron absorption but this does not occur until 7 to ro days after the bleeding, suggesting that increased erythropoiesis rather than loss of iron is the stimulus (Pirzio-Biroli and others, 1958). Repeated phlebotomies produce a very great increase in iron absorption even when no evidence of iron deficiency is present (Price and others, 1962), which is further evidence in favour of this view.

\section{The Transport of Iron}

After absorption, ferric iron circulates in the plasma bound to a specific iron-carrying protein, transferrin. The normal serum transferrin level determined by immunochemical techniques is in the region of $250 \mathrm{mg}$. $/ 100 \mathrm{ml}$. but it is more usually assayed in terms of its iron-binding capacity which is between 250 and $400 \mu \mathrm{g}$./100 ml. Since the normal serum iron level is around $100 \mu \mathrm{g}$. per $100 \mathrm{ml}$. the serum iron-binding capacity (IBC) is normally about $30 \%$ saturated. The regulation of the serum transferrin level is poorly understood. Abnormally high levels are found in pregnancy and in all types of iron deficiency anæmia. A low level is found in infections and in various conditions in which protein synthesis is impaired such as starvation, cirrhosis, the nephrotic syndrome and severe malabsorption states. (Laurell, I958). It is also reduced whenever the iron stores of the body are increased. The mechanism here is uncertain but it is clear that the increased percentage saturation of the IBC found in such cases is due to a decrease in the total IBC as well as to a rise in serum iron level. In primary hæmochromatosis the IBC is usually fully saturated at a level between 200 and $250 \mu \mathrm{g}$. $/ 100 \mathrm{ml}$.

\section{Iron Turnover}

A tracer dose of radioactive iron injected intravenously is rapidly removed from the plasma, the rate of removal being exponential over the first 4 to 8 hours. The rate of removal then tends to diminish progressively until, after about 48 hours, a much slower but again constant rate is found. Pollycove and Mortimer (196r), who have analysed such curves mathematically, postulate that the majority of the iron is transferred to the bone marrow from where there is a slow feedback of iron to the plasma. According to their figures, approximately $37 \mathrm{mg}$. of iron leave the plasma daily for the marrow, of which $23 \mathrm{mg}$. are utilized for hæmoglobin synthesis by the red cell precursors, while $14 \mathrm{mg}$. return to the plasma. Approximately I mg. is exchanged daily between the plasma and the iron stores. Surface counting over various organs confirms that the major site of radioiron uptake is the marrow. The radioactive iron entering the marrow becomes incorporated into maturing erythrocytes and after about 24 hours these begin to appear in the peripheral blood. Subsequently the radioactivity in the circulating red cells rises rapidly, reaching a maximum at the 7 th to roth day after injection. At this time, 80 to $90 \%$ of the dose can be found in the peripheral red cell mass.

A number of factors may affect this typical pattern of radioiron clearance and turnover. Anincreased rate of erythropoiesis leads to a morl rapid removal of the isotope from the plasma. $\mathrm{Al}$ the other inter-compartmental changes described above are more rapid and the percentage utilization of the isotope for hæmoglobin synthesis approaches $100 \%$. In patients with increased iron stores, the pattern is quite different. Because of the greater amount of iron present in the plasma and in the labile marrow iron pool, the administered radioiron is, as it were, diluted and the rate of its transfer to the red cell precursors in the marrow is correspondingly reduced and the plasma clearance prolonged. The slow marrow uptake of the isotope allows a greater percentage of the administered dose to enter the iron stores and surface counting shows a characteristic increase in the uptake by the liver. This change in distribution also causes a reduction in the percentage appearing in the circulating red cells. In addition, it has been suggested by Pollycove and Mortimer (I96r) that the plasma radioactivity curve shows three rather than the usual two components. They suggest that this is due to the feedback of iron to the plasma from two labile pools, the normal marrow pool and, in addition, a labile storage pool. In spite of the slow plasma clearance of the radioiron dose, it is to be stressed that the total amount of iron leaving the plasma for the marrow and iron stores is increased to some $50 \mathrm{mg}$. per day. If the iron overload is the result of a hæmo- 
lytic anæmia or other condition with increased erythropoietic activity the plasma clearance rate may be accelerated in spite of the raised serum iron level and the distribution of the isotope between the marrow and the iron stores may be more normal. Hæmolysis with random red cell destruction will reduce the percentage of radioiron that appears in the peripheral red cell mass since a proportion of the labelled cells will be removed from the circulation before the peak activity can be reached. In refractory hypochromic anæmias with erythroid hyperplasia of the marrow, the increased erythropoietic activity will again be apparent but, since much of the erythropoiesis in these conditions is ineffective, the percentage of the isotope appearing in the peripheral red cells will be greatly reduced (Pitcher, Williams, Shaldon and Smits, 1963).

\section{THE CLINICAL SYNDROME OF HAEMOCHROMATOSIS}

Hæmochromatosis is best considered as a clinical and pathological syndrome since it is becoming increasingly clear that there are many causes of that classical clinical triad-pigmentation, cirrhosis and diabetes. A simple and useful classification in which hæmochromatosis is divided into primary and secondary varieties is shown in Table I. The ætiology, of the primary or idiopathic group is at present the subject of considerable controversy. Nevertheless, the final answer with regard to the role of environmental or genetic factors has yet to be given and it is convenient to separate this group of cases from those in which there is a definite precipitating factor or underlying disease; particularly since the treatment of these two groups is so different. The term hæmochromatosis should be used only when there is definite evidence of tissue damage as well as excess iron deposition. It is not surprising perhaps that there is an overlap with simple hæmosiderosis and that there is a group of intermediate cases which cannot be adequately classified. In practice, the transition of hæmosiderosis to hæmochromatosis is rarely observed in any one patient and the exact relationship between these two states continues to be a major difficulty in our understanding of the pathogenesis of iron storage diseases.

\section{Primary 'idiopathic' haemochromatosis}

There can be no doubt from the large amount of iron found in the body at autopsy, which is of the order of 25 to $50 \mathrm{~g}$. that increased intestinal absorption of iron must have occurred over a prolonged period of time. The nature of the underlying defect and the cause of the cirrhosis and other tissue damage is, however, far from
TABLE I

Classification of Iron Storage Diseases I. Primary 'idiopathic' hæmochromatosis

2. Secondary hæmochromatosis:

(a) Chronic refractory anæmia

(b) Congenital transferrin deficiency

(c) Bantu siderosis

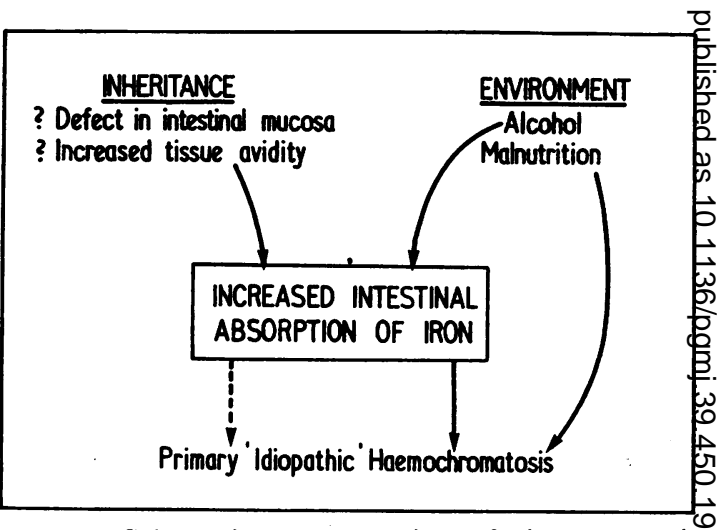

FIG. I.-Schematic representation of the two maifo theories of the atiology of primary idiopathie hæmochromatosis.

clear. The two main schools of thought with their emphasis on either a genetic defect ofo environmental factors (Fig. I) are difficult ț reconcile and for the sake of clarity are f considered separately.

Genetic defect. The presence of a genetic defect is largely based on the reports of familial cases of the disease. The number of such cases is small. Fincl and Finch (1955), for instance, could find only $\overline{\vec{p}}$ histologically proven cases of familial involvemen in a series of 707 patients. A greater number of the immediate relatives may show isolated signs. such as pigmentation, hepatomegaly or a raised serum iron level. Debré, Dreyfus, Frezal, Labie Lamy, Maroteaux, Schapira and Schapira (1958 found that $50 \%$ of male offspring over the age of I $_{5}$ had a raised serum iron value and concludec that this was consistent with a dominant mode of inheritance. Others have reported a lower percent age (Finch and Finch, 1955; Morgan, 196r) an the interpretation of a raised serum iron alone is. difficult owing to the wide range and spontaneous fluctuations observed in normal subjects. Indeed Bothwell, Cohen, Abrahams and Perold (r959ß found normal liver histology and normal irong stores in some of the relatives with raised serumf iron levels, and recently there have been reports of families in which liver biopsy of asymptomatie siblings has shown increased iron deposition in the presence of a normal serum iron levelo (Brick, I96r ; Frey, Milne, Johnson and Ebaugh I96r.) 
The largest series of families studied is that of Williams, Scheuer and Sherlock (1962) who examined clinically and by liver biopsy 46 immediate relatives of 16 patients with idiopathic hæmochromatosis. In 28 relatives liver biopsy sections gave a positive reaction for free iron and in a further 6 excess iron was demonstrable by electron microscopy. Clinical signs of the disease, however, were slight (Fig. 2) and pigmentation of the skin was often the only physical sign. Only one relative, a brother, had a definite cirrhosis, this patient also showing the most marked iron deposition. The serum iron levels in the affected relatives were raised but there was a marked overlap with the normal range and the mean level of the propositi was considerably higher. There appeared, therefore, to be a very distinct difference between the affected relatives and the propositi, not only in clinical signs and serum iron levels but also in biopsy findings.

Mode of inheritance. In most of the family studies, a dominant form of inheritance has been postulated this being qualified by the terms incomplete penetrance or expression in order to explain the small numbers of familial cases and the occurrence of relatives showing some but not all the features of the disease. With a dominant defect, however, only $50 \%$ of each generation should be affected and our figure of $74 \%$ involvement as judged by a positive biopsy for free iron was significantly higher and suggests an intermediate form of inheritance. Here the heterozygous subject with one abnormal gene shows some abnormality. When two heterozygous persons with the abnormal gene marry the children will be affected in the ratio of one abnormal homozygous and two heterozygous siblings to one normal homozygous. In other words, 3 out of 4 will show some signs but only one the full clinical picture (Fig. 3). This form of inheritance is consistent with the much more frequently described involvement of siblings than of children (Peterson, 1960) and is also in accord with reports of the disease occurring as a result of consanguinous matings, which considerably increase the chances of both parents carrying the same abnormal gene.

Nature and site of genetic defect. Since the increased absorption of iron in idiopathic hæmochromatosis occurs in the presence of excess iron stores and with a normal dietary intake it was thought for a long time that the primary defect must be a failure of the normal intestinal mucosal block mechanism. It is unlikely however, as already discussed, that this 'mucosal block' is present in the form originally proposed and it seems more probable that the increased absorption is a secondary phenomenon, and occurs perhaps as a result of increased tissue avidity for iron. Golberg and

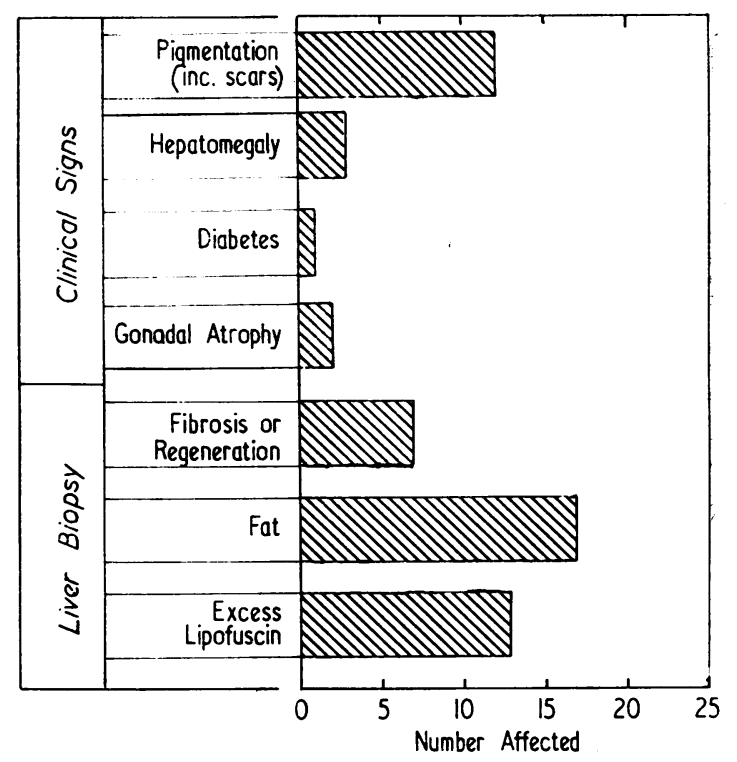

FIG. 2.-The main clinical and biopsy findings in 28 . relatives found to have increased free iron in hepatic biopsy sections on light microscopy (from Williams and others, I962).

Smith (1960) have postulated that excessive amounts of an iron binding protein, which they term haptosiderin is synthesized either in the liver or generally as a result of an inborn error of metabolism. The earliest histological abnormality in the liver in hæmochromatosis appears to be an excess of a lipofuscin-like pigment. Johnson and Frey (1962) found that this was present in liver biopsy sections from relatives which were otherwise normal and showed no excess of free iron. Scheuer, Williams and Muir (1962) suggest that these lipofuscin granules form the organic basis of hæmosiderin deposits since they observed in electron micrographs a gradual transition between these two pigments which differed only in their ferritin content. It is to be noted that a similar excess of a lipofuscin-like pigment has been seen in liver biopsy sections from asymptomatic relatives of patients with Wilson's disease (Schaffner, Sternlieb, Barka and Popper, 1962).

Although the cause of the reduced serum total iron-binding capacity in hæmochromatosis is uncertain, the transferrin present is indistinguishable from normal (Bothwell, Jacobs and Torrance, I962) and there is no evidence to suggest a primary defect in iron transport.

Environmental factors. As a result of their recent studies at the Boston City Hospital, MacDonald and his colleagues have suggested an entirely different pathogenesis (MacDonald and Mallory, I960; 


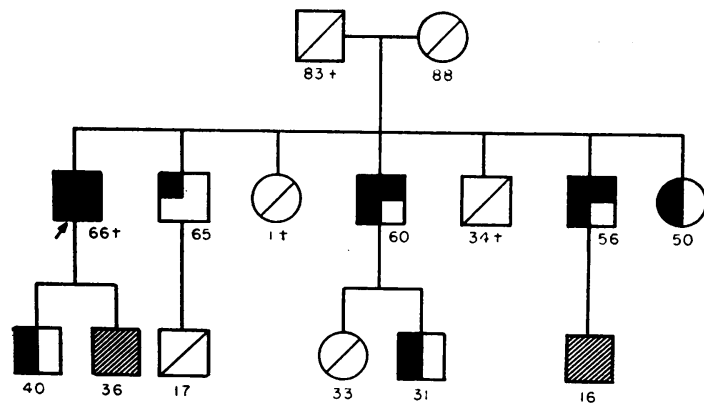

FIG. 3.-Family tree of a patient who died at age of 66 with primary idiopathic hæmochromatosis. Although all 4 siblings examined had excess free iron in liver biopsy sections none showed the full clinical picture of hæmochromatosis. Three had slight pigmentation and in two the liver biopsy sections showed portal tract fibrosis and infiltration in addition to increased iron deposition. True cirrhosis, however, was not present. Direct transmission to the next generation is also shown (from Williams and others, 1962).

KEY :

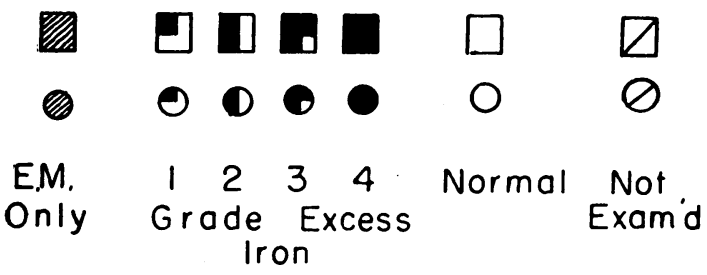

\section{$\gamma$ Propositus}

In key to Pedigree

Grades $\mathrm{I}-4=$ histological grading of amount of iron present in liver biopsy section.

E.M. = Excess iron demonstrable by electron microscopy only.

Numerals indicate current age or ages at death. $\dagger$

MacDonald, I960, I96r; Pechet and MacDonald, 1962). Not only do they question the evidence for a genetic defect but they also doubt the existence of idiopathic hæmochromatosis as a specific disease entity. They believe that the disease is simply a variant of nutritional cirrhosis in which the abnormal absorption and deposition of iron is caused by the same dietary factors that lead to cirrhosis (Fig. I). In support of this view they quote the findings of hæmosiderin deposits in 50 to $80 \%$ of cases of portal cirrhosis, the frequent association of alcoholism with hæmochromatosis and the experimental evidence that iron overloading alone does not produce a typical pigmentary cirrhosis. Both 'idiopathic' hæmochromatosis and nutritional liver disease are unusually frequent at the Boston City Hospital, the incidence of hæmochromatosis being I in approximately 800 deaths as compared with a reported incidence of $I$ i $\stackrel{0}{\text { P. }}$ 7,000 (Finch and Finch, 1955) which agaif 8.uggests a relationship between the two. In their own autopsy series of 57 cases of hæmochromatosig (MacDonald and Mallory, I960) $85 \%$ were. known to have taken alcohol in excess and it three quarters of the remainder there was history of an inadequate diet or a grossly fatt liver at autopsy. The classical inactive type of portal cirrhosis which is seen in idiopathic hæmo $\frac{\bar{\nabla}}{2}$ chromatosis is, they suggest, also consistent witle a previous fatty nutritional cirrhosis from whictor the fat has been mobilised, for a considerable percentage was found to show alcoholic hyalinè and residual fat at autopsy. In this connection $i \vec{t}$ is of interest that $43 \%$ of their patients appeares to have stopped drinking for a number of years prior to admission.

According to this hypothesis the increased absorption and deposition of iron in the liver is secondary to the nutritional disturbance. That this can occur experimentally has been shown amonge others by Kaufman, Klavins and Kinney (1958) who fed rats a low protein diet containing $\vec{a}$ normal amount of iron. MacDonald (1960) found that rats on a choline deficient diet with added iron? absorbed more iron than a control group fed on a normal diet with the same amount of added iron and in addition showed that the final histologieaf picture depended on the duration of feeding. the rats in whom a fatty liver, cirrhosis and ir deposition had been induced by the choline $\overline{0}$ deficient diet were then given a normal diet prion to sacrifice the fat was mobilised from the liver $\stackrel{\mathbb{Q}}{\Omega}$ leaving a portal-type cirrhosis with hæmosiderin deposits very similar to that seen in humang pigment cirrhosis. When the normal diet was? reintroduced before cirrhosis had developed, the्]. liver was relatively normal at autopsy apart from increased iron deposits; a condition which theye. suggest is analogous to the hæmosiderosis occurr-o ing in man.

Simple hæmosiderosis of the liver withoutô evidence of tissue damage is in their experience, extremely common. In a recent series of 125 unselected autopsies and 86 consecutive liver biopsies stainable iron was present in $58 \%$ of histologically normal livers and in $73 \%$ of normaln infant livers (Pechet and MacDonald, 1962). The amount of iron was usually slight, but if oneO interprets their views correctly this condition, $\omega$ which is called idiopathic hæmosiderosis, is but one end of the spectrum resulting from nutritionalo and other environmental factors which finally result in hæmochromatosis. The cirrhosis and? other tissue damage in hæmochromatosis would뭉 therefore be related to, but not caused by, the

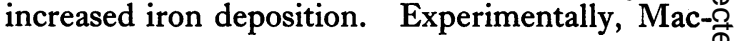


Donald (1960) could find no evidence that the presence of iron accelerated the development of cirrhosis in rats on a cirrhosis-producing diet and auto-radiographic studies showed that iron filled liver cells had a normal life span. On the other hand, Golberg and Smith (1960) found in the rat that the siderotic but otherwise normal liver displayed enhanced susceptibility to the action of ethionine or of diet poor in protein and vitamin E. Although tissue respiration was normal even in the presence of severe siderosis they suggest that a condition of 'equilibrated swamping' exists and that the liver may be rendered more vulnerable to a host of adverse circumstances.

It is to be stressed also that incidence of alcoholism is rarely as high in other series of patients with hæmochromatosis. In the detailed family study of Williams and others (1962) there was a history of alcoholism or malnutrition in only 7 of the 16 propositi and only 3 of the 34 relatives showing increased hepatic iron deposition could be classed as heavy drinkers. Neither do other workers find such an overlap between hæmochromatosis and primarily alcoholic or nutritional liver disease. In only 8 of the I 16 cases of cirrhosis examined by Zimmerman, Chomet, Kulesh and McWhorter (196r) were the hæmosiderin deposits heavy enough to cause difficulty in distinguishing the lesion from idiopathic hæmochromatosis. Similarly, in our series of $\mathrm{I} 6 \mathrm{I}$ consecutive liver biopsies (Scheuer, Williams and Muir, 1962) although some degree of iron deposition was found in over half of the cases of liver disease attributed to alcoholism, in only one did the amount approach that seen in hæmochromatosis.

MacDonald and his colleagues also offer no explanation as to how nutritional deficiences cause increased iron absorption in the presence of a normal iron intake. Golberg and Smith (1960) whose work has already been referred to, suggest that the liver damage occurs first and results in an increased production of an iron binding protein which they term haptosiderin. This would not be compatible with the concept of a simple idiopathic hæmosiderosis. The recent studies of iron kinetics in Lænnec's cirrhosis by Conrad, Berman and Crosby (1962) are of particular interest. Three of their patients had high serum iron levels and in one excess iron deposits were also demonstrated in liver and marrow sections. The percentage absorption of iron was considerably increased in all three and indeed comparable to that found in 3 others with cirrhosis who had bled previously and were iron deficient at the time of study. The remaining 4 cirrhotic patients studied showed normal iron absorption. Many factors may affect the state of iron balance in cirrhosis but it is clear from these findings that some patients have markedly increased iron absorption in spite of the presence of excessive iron stores. Recently a few cases have been described of hæmochromatosis developing in patients with cirrhosis within a few years of portacaval anastomosis, biopsy at the time of operation having shown no abnormal iron deposition (Schæfer, Amick, Oikawa and Schiff, r962). It seems likely that these are due to continuing increased absorption of iron with lessening of the amount of blood loss from varices and thrombocytopenia rather than to an effect of the anastomosis itself on iron absorption.

In summary, the well substantiated reports of familial cases and the high incidence of hæmosiderosis in the relatives indicate a genetic defect in idiopathic hæmochromatosis. Its frequency suggests that this is inherited as an intermediate characteristic and the development of hæmochromatosis will therefore depend on the presence of two abnormal genes. It is possible, however, that environmemtal factors rather than variation in genetic dose are responsible for the full development of the disease. Indeed a great deal of evidence both in man and experimentally in animals points to a relatioship between hæmochromatosis and alcoholism. Unfortunately little is known about the early stages of hæmochromatosis since the patient rarely presents until the advance stages of the disease. The frequency with which simple hæmosiderosis occurs in the general population is clearly very important and requires further. study. The findings at the Boston City Hospital refer to a special social and economic group and may not apply to other areas. Hospital and autopsy control series are inevitably selective and even cases of accidental death are not necessarily random. Such information is difficult to obtain but careful follow up of the relatives with hæmosiderosis and similar systematic studies of the families of patients with other varieties of cirrhosis may help to elucidate the problem.

\section{Secondary Hæmochromatosis}

(a) Chronic refractory anamia ('Transfusional' hamochromatosis). Secondary hæmochromatosis was first described in patients with aplastic anæmia treated by multiple blood transfusions. True hæmochromatosis, as opposed to simple hæmosiderosis, is however an extremely rare complication of this type of anæmia. It occurs much more frequently in a group of conditions in which a refractory hypochromic anæmia is found in association with a hyperplastic marrow. One such condition, refractory normoblastic anæmia (Dacie, Smith, White and Mollin, 1959) is often referred to as a sideroblastic anæmia 
since the normoblasts show a characteristic perinuclear ring of hæmosiderin granules in the cytoplasm. The underlying defect is believed to be a block in the utilization of iron for hæmoglobin synthesis, coupled with the destruction of maturing erythroblasts within the marrow before they can be released into the peripheral blood. This change, referred to as 'ineffective erythropoiesis' or 'intramedullary hæmolysis' probably accounts for the great degree of marrow hyperplasia that is present. Occasionally the condition appears to be secondary to pyridoxine deficiency but in the majority of cases the cause in unkown. Another condition in which faulty hæmoglobin synthesis is associated with marrow hyperplasia is thalassæmia and a moderate degree of hæmosiderosis is common in this condition. Only a small percentage, however, develop the full clinical and pathological picture of hæmochromatosis.

In purely hæmolytic anæmias secondary hæmochromatosis is much rarer. Among the possible explanations for this are the absence of any interference with hæmoglobin synthesis and the fact that only in the severest cases does the degree of marrow hyperplasia approach that seen in the refractory sideroblastic anæmias.

This association of secondary hæmochromatosis with various types of chronic refractory anæmia having, in common, marrow hyperplasia is of particular interest in relation to the pathogenesis of the iron deposition and tissue damage. It was thought initially that the most important factor in these cases was the number of transfusions that they had received and indeed the condition was often referred to as transfusional hæmochromatosis. Cases were observed however which had received few or no transfusions (reviewed by Block, 1958) and it was also noted that the amount of iron present in the tissue at autopsy was often greater than that known to have been given. All this pointed to an increased intestinal absorption of iron. It seems very likely now that this is due to the increased erythropoiesis and marrow hyperplasia present in these cases, since the rate of erythropoiesis has been shown, as already discussed, to be one of the most important factors regulating the rate of iron absorption.

There is also some evidence to suggest that it is the iron derived from increased intestinal absorption rather than that coming from the transfused blood that is responsible for the liver damage. Cappell, Hutchinson and Jowett (1959) examined in detail 5 cases of aplastic anæmia which had been treated with multiple blood transfusions over prolonged periods of time. In two of these the liver contained over $50 \mathrm{~g}$. of iron which is approximately twice that present in idiopathic hæmochromatosis, yet there was no cirrhosis.
They emphasized that considerable widening $\stackrel{\leftrightarrow}{\overrightarrow{4}}$ the portal tracts can occur in simple hæmæ. siderosis as a result of the accumulation the of engorged Kupffer cells. Lack of awareness of this in the past may have led to the description of such cases as showing early periportal cirrhosi They reviewed all the previous cases of trans fusional siderosis in the literature in whic chemical estimation of iron content had bee performed and found that when a true cirrhos was present the amount of iron recovered was always considerably in excess of that known to have been transfused. When there was no cirrhosis the amount recovered was only 5 to $40 \%$ of that given. The latter is what would be expected since blood loss by hæmorrhage is common in these case They postulated that the reaction of the body to ex: cess iron depended on the site of entry. Iron derived from the gut may be frankly irritant whereas that released from effete red cells is relativel 感 bland, perhaps as a result of the prior passage through the reticulo-endothelial system.

This view is also consistent with the more recent findings of Kent and Popper (1960) whō examined the distribution of iron in a series, of patients with varying types of anæmia who ha. siderosis but no hepatic fibrosis. They found two basic patterns. In purely hæmolytic anæn⿺廴⿱㇒⿵⺆⿻二丨冂⿻ iron was confined almost entirely to the reticusoendothelial system wheras in thalassæmia, chrōif refractory anæmias and to some extent in sickes cell anæmia the iron appeared to be deposite preferentially in the parenchymal cells of the lives and other organs. The purest forms of parenchy mal siderosis were observed in three cases who hat not received blood transfusions or parenteral irow therapy. It is from this group of anæmias, as we have already seen that cases of secondary hæmo? chromatosis are derived. Kent and Popper also compared the histological appearances in the liver. in 5 cases of secondary hæmochromatosis ang anæmia, with those present in the very early stage of idiopathic hæmochromatosis (two of theis patients had died early in the course of the disease from unrelated conditions). The basio structural alterations appeared to be similar to both though the process appeared to be more. active in secondary hæmochromatosis. In botf instances hepatocellular degeneration and ductular proliferation was observed around the entire circumference of the portal tract which is the site of the earliest and highest concentration of iron pigment. This diffuse enlargement an $\$$ configuration of the portal tracts is, in theig experience, quite different from the stellate appearance seen in 'alcoholic' cirrhosis.

The role of blood transfusions in the develop ment of this condition is therefore to prolong life 


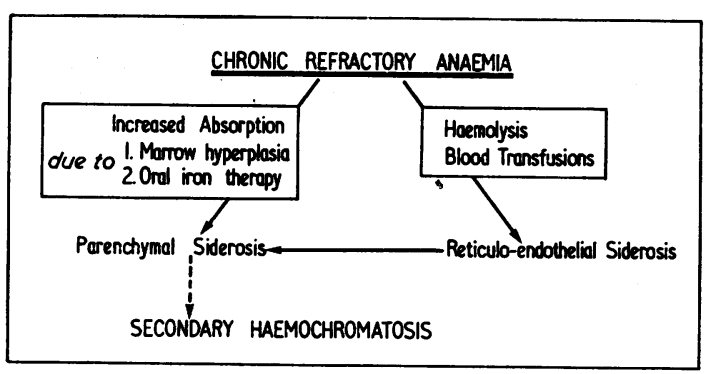

Fig. 4.-The origin and sites of distribution of excess tissue iron in secondary hæmochromatosis associated with chronic refractory anæmia.

and so make the appearance of the disease possible. Together with hæmolysis they produce a reticuloendothelial siderosis, and possibly may finally aggravate the disease as a result of redistribution of the iron (Fig. 4). It is important to emphasize also that oral iron therapy is of no value in these patients with chronic refractory anæmia and indeed is positively dangerous for it will hasten the development of hæmochromatosis.

(b) Congenital transferrin deficiency. Heilmeyer, Keller, Vivell, Keiderling, Betke, Wöhler and Schultze (I96I) have recently reported the first case of congenital transferrin deficiency. This was a 7 year-old girl who was referred for investigation of a refractory iron-deficiency anæmia. Anæmia had first been noted at the age of three months and both parents had a reduced transferrin level. She died suddenly and at autopsy was found to have large amounts of iron in all the tissues with the exception of the marrow. Section of the liver showed a finely nodular cirrhosis and the pancreas was fibrotic. It was suggested that as a result of the transferrin deficiency absorbed iron rapidly leaked out through the capillaries and inadequate amounts reached the marrow for hæmoglobin synthesis. The combination of a very low serum iron level with a fully saturated I.B.C. is diagnostic of this condition.

(c) Siderosis of the Bantu. Approximately $80 \%$ of adult Bantu subjects coming to autopsy have increased iron deposits. The siderosis is usually an incidental finding and unrelated to the cause of death. The frequency with which it occurs and the extent of the deposits appear to increase with age and undoubtedly one of the most important ætiological factors is the high iron content of the average Bantu diet. These people are predominantly maize eaters and although maize is not particularly rich in iron, the content is considerably increased by the traditional method of cooking in iron pots. These are also used in the preparation of fermented porridge and Kaffir beer and a typical diet may contain as much as 100 to $150 \mathrm{mg}$. of iron per day (Walker and Arvidsson, 1950).

Studies of the distribution of the iron deposits in these cases has shown two distinct patterns. In the milder cases the iron is found predominantly. in the reticulo-endothelial system, notably in spleen, bone-marrow and lymph nodes. Some, however, is always present in the parenchymal cells of the liver but deposits in other parenchymal organs such as pancreas, heart and thyroid are unusual. One other interesting and rather characteristic finding is heavy pigmentation of the jejunum which is rarely seen in the other varieties of hæmochromatosis. In these mild cases there is little evidence of tissue damage from the iron though the liver may show varying degrees of portal tract fibrosis. A small proportion of the patients with severe siderosis show a different picture and have what appears to be a true pigmentary cirrhosis. In these cases, in contrast to the previous group, the pancreas and other parenchymal organs show heavy iron deposition. Clinically they may show all the features of primary idiopathic hæmochromatosis. Seftel, Keeley and Isaacson and Bothwell (I96I) screened a random group of roo Bantu subjects with diabetes and found 7 with the fully developed disease as judged by hepatomegaly, high serum iron level and a definite cirrhosis on biopsy.

Recent work suggests that it is the presence or absence of cirrhosis rather than the degree of iron overload which determines the pattern of iron distribution. Bradlow, Dunn and Higginson (I96I) found that extrahepatic parenchymal deposition of iron was significantly increased only in those cases with a true histological cirrhosis. Isaacson, Seftel, Keeley and Bothwell (I96I) reported essentally the same. The average iron content of the liver in their cases with severe siderosis alone was $2.2 \mathrm{I}$ g. per $100 \mathrm{~g}$. dry weight as compared with an average level of $2.31 \%$ in a group with severe siderosis and cirrhosis; yet only in the latter patients was there a significantly increased concentration of iron in the pancreas, heart, adrenal, thyroid and testis. It is possible that the extrahepatic parenchymal deposition of iron in the cases is related to the higher percentage saturation of the serum iron-binding capacity. Although the serum iron level is raised in the majority of cases of Bantu siderosis, only in those with cirrhosis is the degree of saturation markedly increased. Wainwright (1957) for instance found that in only 4 out of 17 cases without cirrhosis was the saturation greater than $50 \%$ whereas in 13 cases with cirrhosis the total iron binding capacity was 62 to $97 \%$ saturated. The increase in percentage saturation in these cases is due, as in idiopathic hæmochromatosis, to a decrease in total iron 
binding capacity as well as to a rise in serum iron level. The cause of the decreased serum ironbinding capacity and its exact relationship in time to the development of cirrhosis and iron deposition in other organs requires further study.

It is clear from these and other studies, that the development of cirrhosis cannot be accounted for simply on the basis of increasing iron deposition. Indeed several of the cases studied by Isaacson and his colleagues ( 1961 ) had concentrations of iron in the liver which were lower than in those with marked siderosis but no cirrhosis. Some additional factor is required. Malnutrition is common in the Bantu and since a large proportion of the iron ingested is derived from containers used in the preparation of alcholic drinks it follows that those with marked siderosis are usually heavy drinkers. It is to be noted, however, that up to the stage of cirrhosis there appears to be a definite correlation between the incidence of portal tract fibrosis and the concentration of iron in the liver (Bothwell and Bradlow, 1960).

\section{The Measurement of Iron Absorption in Hæmochromatosis}

Relatively little work has been done on iron absorption in primary 'idiopathic' hæmochromatosis. It can be seen from Table 2 which gives the results of the main studies to date, that in the majority of cases absorption has been measured indirectly by stool counting after oral administration of ${ }^{59} \mathrm{Fe}$, this usually being given in the form of an inorganic ferrous salt. Out of a total of 15 such cases in the literature only 3 were found to have increased absorption. These three cases, which represent the single patient studied by Alper, Savage and Bothwell (195I) and two of the 4 cases in the later series of Bothwell, van Doorn-Wittkampf, Du Preez and Alper (1953), absorbed $62 \%, 51 \%$ and $72 \%$ respectively of the administered dose. Increased percentage absorption was also found in the three cases reported in which ferric iron was used and in two cases investigated by Chodos and others (1957) who gave ${ }^{59} \mathrm{Fe}$ incorporated into food iron. The inherent difficulties of stool counting methods and the unphysiological nature of some of these tests have already been stressed and it is difficult to know how much reliance should be placed on this finding of normal iron absorption in many cases of idiopathic hæmochromatosis. Pirzio-Biroli and others (1958) using the better double isotope method found a higher mean absorption in 4 cases of idiopathic hæmochromatosis (10\% as compared with normal mean of $5.3 \%$ ) although the individual results fell within the normal range and the difference in mean value with the small number of cases studied is not significant. The commonest age of presentation, however, is the fifth decade and it is clear therefore that only a small percentage increase in absorption would be necessary t\$ account for the amounts of iron found in these. cases, provided it óccurs over a prolonged period: of time. This may be difficult to demonstrate using methods which have such a wide range in normal subjects. Part of this wide range, is undoubtedly due to the inclusion of subjects if normal series who are not really in a state of norma iron balance. Even the mildest iron deficiency math be associated with considerably increased absorp $\overrightarrow{0}$ tion rates and subjects should only be included in. normal series if their serum iron level is normal asu well as the peripheral blood picture. If possiblo normal erythropoietic activity should also have been demonstrated by marrow examination. Ideally the control series and the group of patientso with idiopathic hæmochromatosis who are being investigated should also be comparable wit? respect to age, sex and social class.

Increased iron absorption has been describe in a few patients studied either during or after venesection therapy (Table 2 ). The three cases investigated by Pirzio-Biroli and others (1958) were. examined at a time when tissue stores were stili. increased. The interpretation of such studieß if difficult. The amount of iron absorbed depend not only on the state of the iron stores Buf also on the degree of increased erythropoietie activity present; since the rate of erythropoiesis is one of the most important factors which normally regulate iron absorption.

There is also little information available regarding iron absorption in the various condition $\$$ associated with secondary hæmochromatosis. The case of secondary hæmochromatosis and refractory anæmia studied by Dubach and others (1948 absorbed $27 \%$ of a dose of ${ }^{59} \mathrm{Fe}$ given as a ferrous. salt, the range in normal subjects being 2 to $21 \%$ Price and others (1962) found considerabl increased absorption in a patient with refractor\% sideroblastic anæmia and iron overload using the whole-body counting method. Four out of 5 cases of Bantu siderosis investigated by Bothwell and his colleagues (I953) had percentage absorptions. falling within the normal range. In the fifth case, who had cirrhosis and diabetes absorption was increased.

In conclusion, it is clear from the large amountso of iron found in the tissues at autopsy both ie primary idiopathic hæmochromatosis and io Bantu siderosis-hæmochromatosis that increase $\bar{\Phi}$ intestinal absorption of iron must occur. There is also considerable indirect evidence supported by a few measurements, that this also occurs in 8 particular variety of chronic refractory anæmi 
TABLE 2

Results of Iron Absorption Studies in Primary 'Idiopathic' Hemochromatosis (Except where indicated the cases were untreated at the time of the study)

\begin{tabular}{|c|c|c|c|c|}
\hline Authors & Method & No. of $\mathrm{Pa}$ & $\begin{array}{l}\text { Percentage } \\
\text { Absorption }\end{array}$ & Normal Range* \\
\hline Dubach and others (1948) & $\begin{array}{l}\text { Stool counting after oral } \\
{ }^{5} \mathrm{Fe} \text { as ferrous salt }\end{array}$ & $\mathbf{I}$ & $21 \cdot 5$ & $2-21 \%(10)$ \\
\hline $\begin{array}{l}\text { Alper and others (195I) } \\
\text { Bothwell and others (I 953) }\end{array}$ & ,", & $\begin{array}{l}\text { I } \\
4\end{array}$ & $22,22,51,72$ & $\begin{array}{c}14 \%(1) \\
9-25 \%(4)\end{array}$ \\
\hline $\begin{array}{l}\text { Peterson and Ettinger } \\
\text { (1953) }\end{array}$ & $\begin{array}{l}\text { Stool counting after oral } \\
{ }^{59} \mathrm{Fe} \text { as ferric salt }\end{array}$ & $\begin{array}{c}\text { I } \\
\text { I }(3 \text { months after } \\
\text { venesection therapy })\end{array}$ & $\begin{array}{c}44 \cdot 7 \\
20\end{array}$ & $1.5-4.4 \%(4)$ \\
\hline Chodos and others (1957) & $\begin{array}{l}\text { Stool counting: } \\
\text { (a) After oral }{ }^{59} \mathrm{Fe} \text { as } \\
\text { ferrous salt } \\
\text { (b) After }{ }^{59} \mathrm{Fe} \text { incor- } \\
\text { porated in food }\end{array}$ & $\begin{array}{l}9 \\
2\end{array}$ & $\begin{array}{l}5-30 \\
20,27\end{array}$ & $\begin{array}{l}4-33 \%(10) \\
0.5-10 \%(2)\end{array}$ \\
\hline $\begin{array}{l}\text { Pirzio-Biroli and others } \\
\quad\left(195^{8}\right)\end{array}$ & $\begin{array}{l}\text { Double isotope tech- } \\
\text { nique. Ferric iron in } \\
\text { labelled meal }\end{array}$ & $\begin{array}{l}4 \\
3 \text { (during venesection } \\
\text { therapy) }\end{array}$ & $\begin{array}{c}4.8,7.0, \text { I } 1.4, \text { I } 7.0 \\
\text { Mean } 10.0 \\
29.4,29.7,29.7\end{array}$ & $\begin{array}{c}0.5-16.6 \%(24) \\
\text { Mean } 5.3\end{array}$ \\
\hline
\end{tabular}

*The number of normal subjects studied is shown in brackets.

which is liable to develop secondary hæmochromatosis. This increased absorption, however, may not be a continuous process and it is clear that much work has to be done on the measurement of iron absorption at different stages of the disease. It is possible for instance that the development of cirrhosis or pancreatic insufficiency may markedly affect the underlying rate of absorption. The influence of various environmental factors such as alcoholism and dietary deficiencies, which appear to be important ætiological factors in at least some cases of hæmochromatosis, has also been inadequately studied. The measurement of iron absorption in the relatives of patients with idiopathic hæmochromatosis will be of great interest. Controversy as to the exact role played by excess iron in the development of tissue damage in this group of diseases and the numerous experimental studies designed to test one or other hypothesis have tended in the past to overshadow this important aspect of their pathogenesis. Now that better methods are available for the study of iron absorption and tissue distribution a clearer picture should emerge.

\section{REFERENCES}

Alper, T., Savage, D. V., and Bothwell, T. H. (I95 I): Radioiron Studies in a Case of Hæmochromatosis, $\mathcal{Y}$. Lab. clin. Med., 37, 665.

Biggs, J., Bannerman, R., and Callender, S. T. (1962): Iron Absorption in Achlorhydria, Proc. 8th Congr. Europ. Soc. Hamat., Vienna, r96r, p. 236.

Block, M. (1958): Hæmosiderosis and Hæmochromatosis. II. In Iron in Clinical Medicine. Ed. R. O. Wallerstein and S. R. Mettier, p. I I 5. Berkeley and Los Angeles, California: University of California Press.

Bothwell, T. H., van Doorn-Wittkampf, H. V., Du Preez, M. L., and AlPer, T. (r 953): The Absorption of Iron: Radioiron Studies in Idiopathic Hæmochromatosis, Malnutritional Cytosiderosis and Transfusional Hæmochromatosis, F. Lab. clin. Med., 4I, 836 .

, Pirzio-Biroli, G., and Finch, C. A. (1958): Iron Absorption. I. Factors Influencing Absorption, F. Lab. clin. Med., 5I, 24.

, Cohen, I., Abrahams, O. L., and Perold, S. M. (1959): A Familial Study in Idiopathic Hæmochromatosis, Amer. F. Med., 27, 730.

and Bradlow, B. A. (1960): Siderosis in the Bantu: A Combined Histopathological and Chemical Study, Arch. Path., 70, 279.

, JacoBs, P., and Torrance, J. D. (1962): Studies on the Behaviour of Transferrin in Idiopathic Hæmochromatosis, S. Afr. Ұ. med. Sci., 27, 35 .

Bradlow, B. A., Dunn, J. A., and Higginson, J. (I96r): The Effect of Cirrhosis on Iron Storage, Amer. F. Path., 39, 221.

Brick, I. B. (I96I): Liver Histology in Six Asymptomatic Siblings in a Family with Hæmochromatosis: Genetic Implications, Gastroenterology, 40, 210.

Callender, S. T. (1962): Iron Metabolism using Iron $59\left({ }^{50} \mathrm{Fe}\right)$ as a Tracer, Proc. roy. Soc. Med., $55,145$.

Cappell, D. F., Hutchison, H. E., and JowetT, M. (1957): Transfusional Siderosis: The Effects of Excessive Iron Deposits on the Tissues, F. Path. Bact., 74, 245.

Chodos, R. B., Ross, J. F., Apt, L., Pollycove, M., and Halkett, J. A. E. (1957): The Absorption of Radioiron Labelled Foods and Iron Salts in Normal and Iron Deficient Subjects and in Idiopathic Hæmochromatosis, f. clin. Invest., 26, 314 . 
Conrad, M. E., Berman, A., and Crosby, W. H. (1962): Iron Kinetics in Laennec's Cirrhosis, Gastroenterology, 43, 38 迎

Dacie, J. V., Smith, M. D., White, J. C., and Mollin, D. L. (1959): Refractory Normoblastic Anæmia: A Clinica隹 and Hæmatological Study of Seven Cases, Brit. Y. Hamat., 5, 56.

Debre, R., Dreyfus, J. C., Frezal, J., Labie, D., Lamy, J., Maroteaux, P., Schapira, F., and Schapira, G. (i958) 西 Geneties of Hæmochromatosis, Ann. hum. Genet., 23, 16.

Dubach, R., Callender, S. T., and Moore, C. V. (1948): Studies in Iron Transportation and Metabolism: Absorption. of Radioactive Iron in Patients with Fever and with Anæmias of Varied Etiology, Blood, 3, 526.

FInCH, S. C., and FInCH, C. A. (1955): Idiopathic Hæmochromatosis: Iron Storage Disease, Medicine, 34, 38 I.

Frey, W. G., Milne, J., Johnson, G. B., and Ebaugh, F. G. (196r): Management of Familial Hæmochromatosis̄o New Engl. F. Med., 265, 7.

Golberg, L., and Smith, J. P. (1960): Iron Overloading and Hepatic Vulnerability, Amer. F. Path., 36, 125.

Granick, S. (1946): Protein Apoferritin and Ferritin in Iron Feeding and Absorption, Science, 103, 107.

Heilmeyer, L., Keller, W., Vivell, O., Keiderling, W., Betke, K., Wöhler, F., and Schultze, H. E. (ig6i)@ Congenital Transferrin Deficiency in a Seven-Year-Old Girl, Germ. med. Mth, 6, 385 .

Isaacson, C., Seftel, H. C., Keeley, K. J., and Bothwell, T. H. (r96I): Siderosis in the Bantu: The Relationship between Iron Overload and Cirrhosis, Ұ. Lab. clin. Med., 58, 845.

Johnson, G. B., and Frey, W. G. (1962): Familial Aspects of Idiopathic Hæmochromatosis, 7. Amer. med. Ass., 179, 747Kent, G., and PoPPER, H. (1960): Secondary Hæmochromatosis: Its Association with Anæmia, A.M.A. Arch. Path 70, 623 .

Kaufman, N., Klavins, J. V., and Kinney, T. D. (1958): Excessive Iron Absorption in Rats Fed Low-protein, Higß Fat Diets, Lab. Invest., 7, 369.

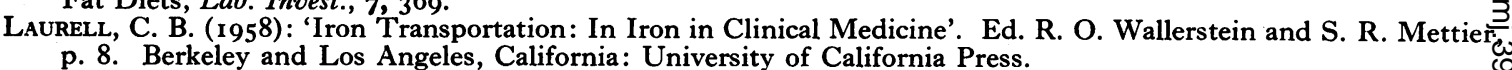

MacDonald, R. A. (1960): Experimental Pigment Cirrhosis: Its Production in Rats by Feeding a Choline-deficienit Diet with Excess Iron, Amer. F. Path., 36, 499.

- (196r): Idiopathic Hæmochromatosis: A Variant of Portal Cirrhosis and Idiopathic Hæmosiderosis, A.M.A. Arch. intern. Med., ro7, 606.

and MALlORY, G. K. (1960): Hæmochromatosis and Hæmosiderosis: Study of 2 I I Autopsy Cases, Ibid., ro5, 686

Moore, C. V., Dubach, R., Minnich, V., and Roberts, H. K. (r944): Absorption of Ferrous and Ferric Radioactive Iron by Human Subjects and by Dogs, $\mathcal{F}$. clin. Invest., 23, 755 .

(1955): The Importance of Nutritional Factors in the Pathogenesis of Iron Deficiency Anæmia, $\mathcal{F}$. clin. Nutr., 3, 37

Morgan, E. H. (1961): Idiopathic Hæmochromatosis: A Family Study, Aust. Ann. Med., ro, 114.

Pechet, G. S., and MacDonald, R. A. (1962): Idiopathic Hæmosiderosis: Relation to Idiopathic Hæmochromatosis New Engl. Y. Med., 267, 6.

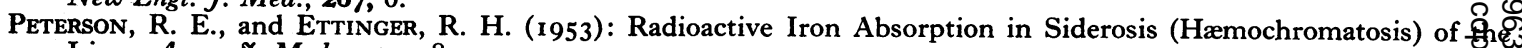
Liver, Amer. F. Med., I5, 5 I8. (r960): In "The Metabolic Basis
Frederickson, p. 856 . New York:

.Pirzio-Biroli, G., Bothwell, T. H., and Finch, C. A. (1958): Iron Absorption. II. The Absorption of Radioirom? Administered with a Standard Meal in Man, $\boldsymbol{F}$. Lab. clin. Med., 5r, 37.

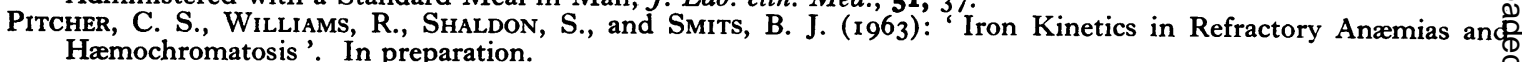
Pollycove, M., and Mortimer, R. (1961): The Quantitative Determination of Iron Kinetics and Hæmoglobin Syn $\overrightarrow{0}$
thesis in Human Subjects, $\mathcal{F}$. clin. Invest., 40, 753.

Price, D. C., Cohn, S. H., Wasserman, L. R., Reizenstein, P. G., and Cronkite, E. P. (ig62): The Determination of Iron Absorption and Loss by Whole Body Counting, Blood, 20, 517.

Schaffner, F., Sternlieb, I., Barka, T., and Popper, H. (1962): Hepatocellular Changes in Wilson's Disease? Histochemical and Electron Microscopic Studies, Amer. F. Path., 4I, 3 I 5.

Scheuer, P. J., Williams, R., and Muir, A. R. (I962): Hepatic Pathology in Relatives of Patients with Hæmo chromatosis, F. Path. Bact., 84, 53.

Schaefer, J. W., Amick, C. J., Oikawa, Y., and Schiff, L. (1962): The Development of Hæmochromatosis Following Portacaval Anastomosis, Gastroenterology, 42, 181 .

Seftel, H. C., Keeley, K. J., IsaAcson, C., and Bothwell, T. H. (196r): Siderosis in the Bantu: The Clinicab Incidence of Hæmochromatosis in Diabetic Subjects, $\mathfrak{F}$. Lab. clin. Med., 58, 837.

Sheldon, J. H. (1935): 'Hæmochromatosis'. London: Oxford University Press.

Smith, M. D., and Pannaciulli, I. M. (1958): Absorption of Inorganic Iron from Graded Doses: Its Significance in Relation to Iron Absorption Tests and the 'Mucosal Block' Theory, Brit. $\mathcal{~}$. Hamat., 4, 428.

Turnbull, A., Cleton, F., and Finch, C. A. (I962): Iron Absorption. IV. The Absorption of Hæmoglobin Iron, F. clin. Invest., 4r, 1897 .

VAN HoEk, R., and ConRad, M. E. (r96I): Iron Absorption: Measurement of Ingested Iron 59 by a Human Whole ${ }^{\circ}$ Body Liquid Scintillation Counter, Ibid., 40, I 153.

Wainwright, J. (1957): Siderosis in the African, S. Afr. F. Lab. clin. Med., 3, r.

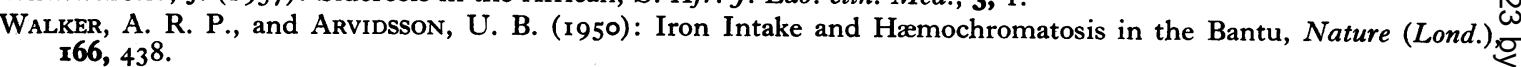

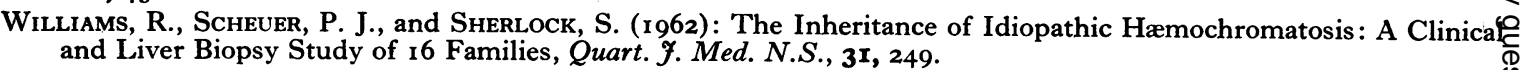

Wöhler, F., Heilmeyer, L., Emrich, D., and Kang, S.: Zur Funktion des Ferritins bei der Eisenresorption, Arch $\stackrel{\mathscr{A}}{+}^{+}$ exp. Path. Pharmak., 230, 107.

Zimmerman, H. J., Chomet, B., Kulesh, M. H., and McWhorter, C. A. (r96r): Hepatic Hæmosiderin Deposits, Incidence in $55^{8}$ Biopsies from Patients With and Without Intrinsic Hepatic Disease, A.M.A.Arch. intern. Med.尺 I07, 494 . 